\title{
Effects of Nitrogen Fertilization and Soil Inoculation of Sulfur-Oxidizing or Nitrogen-Fixing Bacteria on Onion Plant Growth and Yield
}

\author{
Nemat M. Awad, ${ }^{1}$ A. A. Abd El-Kader, ${ }^{2}$ M. Attia, ${ }^{1}$ and A. K. Alva ${ }^{3}$ \\ ${ }^{1}$ Agricultural Microbiology Department, National Research Centre, Cairo 12311, Egypt \\ ${ }^{2}$ Soil and Water Use Department, National Research Centre, Cairo 12311, Egypt \\ ${ }^{3}$ United States Department of Agriculture-Agricultural Research Service, Vegetable and Forage Research, Prosser, WA 99350, USA
}

Correspondence should be addressed to A. K. Alva, ashok.alva@ars.usda.gov

Received 25 June 2011; Revised 9 September 2011; Accepted 3 October 2011

Academic Editor: Ravindra N. Chibbar

Copyright (c) 2011 Nemat M. Awad et al. This is an open access article distributed under the Creative Commons Attribution License, which permits unrestricted use, distribution, and reproduction in any medium, provided the original work is properly cited.

\begin{abstract}
A field experiment was conducted in a newly reclaimed soil at El-Saff region, El-Giza Governorate, Egypt to study the effects of different rates of nitrogen ( $\mathrm{N}$ : 62 to $248 \mathrm{~kg} \mathrm{ha}^{-1}$ ) with or without soil inoculation of sulfur- (S-) oxidizing bacteria (SoxB) and combined inoculation of SoxB and N-fixing bacteria (NFxB) on yield, quality and nutritional status of onion (Allium cepa L.,

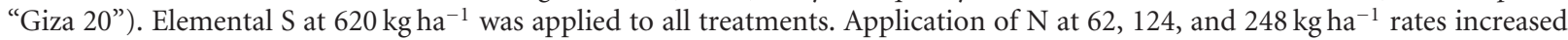
onion yield, plant height, and $\mathrm{N}$ uptake by 28 to $76 \%$, 32 to $53 \%$, and 61 to $145 \%$, as compared to those of the plants that received no N. Inoculation of SoxB at various N rates increased onion yields by 47 to $69 \%$ and N uptake by 76 to $93 \%$, as compared to those of the plants which received the respective rates of $\mathrm{N}$ but no SoxB inoculation. Inoculation with SoxB and NFxB increased onion yield by $221 \%$, plant height by $62 \%$, and $\mathrm{N}$ uptake by $629 \%$, as compared to those of the plants grown without inoculation and no $\mathrm{N}$ applied.
\end{abstract}

\section{Introduction}

Recommendation of optimal nitrogen (N) fertilization strategy and improvement of $\mathrm{N}$ management efficiency heavily rely on precise evaluation of $\mathrm{N}$ status in plant-soil system. For most annual crops, $\mathrm{N}$ is generally applied as a base dressing before planting. Prolonged lag time between $\mathrm{N}$ application to the soil and its maximum crop uptake, following seedling emergence and rapid growth, may result in $\mathrm{N}$ leaching below the rootzone, hence not available for plant uptake. To maximize the benefits of $\mathrm{N}$ nutrition and to ensure adequate $\mathrm{N}$ availability throughout the growing season, additional $\mathrm{N}$ application later during the growing season may be required. Therefore, it is important to follow an optimized $\mathrm{N}$ fertilizer application as per recommended or accepted procedures for high yields and quality of onion production [1].

Sulfur (S) is needed by plants and microorganisms, and its speciation in soil is dependent on the chemical state of the soil, including (1) redox potential, that is, tendency of the soil solution to either gain or lose electrons and thereby suggests the aerobic or anaerobic status of the soil and (2) soil acidity [2]. Plant availability of $S$ in a given soil is dependent on the $S$ speciation in soils, influenced by pedogenetic processes and physicochemical factors, that is, water logging. The oxidation of $\mathrm{S}$ to $\mathrm{SO}_{4}{ }^{2-}$ in soil is a biological process and is carried out by several kinds of microorganisms, that is, Thiobacillus thiooxidans, T. ferrooxidans, T. thioparus, T. denitrificans, and T. novellus. The rate at which this conversion takes place is determined by three main factors, that is, microbiological population in the soil, physical properties of the $S$ source, and environmental conditions. Most agricultural soils contain some microorganisms that are able to oxidize S. However, the most important organisms in $\mathrm{S}$ oxidization are a group of bacteria (SoxB) belonging to the genus Thiobacillus. The population density of these bacteria generally determines the degree to which $\mathrm{S}$ is converted to $\mathrm{SO}_{4}{ }^{2-}$ in soils. Population density of Thiobacillus can vary substantially in different soils. Under laboratory conditions, the rate 
of $\mathrm{S}$ oxidation in some soils can be markedly increased by inoculation with Thiobacillus [3]. However, under field conditions, inoculation has not been found very effective. The population of S-oxidizing bacteria increases in the soil following application of $S$ product.

Sulfur (S) is an essential plant nutrient; however, its content in the soil is only about $10 \%$ of that of the total $\mathrm{N}$ [4]. Therefore, investigations on the $S$ nutrition of plants are rather few, since in most cases, $\mathrm{S}$ content in the fertilizers and atmospheric deposition supplies an adequate amount [5].

Reduced S inputs from atmospheric depositions during recent years resulted in a negative $S$ balance in agricultural soils, since crop plants have become increasingly dependent on the soil to supply crop need for $S$ [6]. Insufficient $S$ availability leads to decreased yields and reduced $S$ content in the plant products under extreme deficiency [7]. Most of the $S$ in soils is bound to organic molecules, and therefore not readily available to plants. Use of $S$ oxidizers enhances the rate of natural oxidation of $S$ and production of sulfates and makes them available to plants at their critical stages, resulting in increased plant yield [8]. In microbial oxidation of inorganic $\mathrm{S}$ compounds, the reactions often mimic chemical models, but the intermediates formed chemically interact with each other making the pathway complex [9]. The requirement of $S$ mainly differs between crop species and developmental stage of plants. Sulfur requirement is much greater for Sunflower as compared to that for wheat and soybean. The $S$ requirement is quite low during early growth stages for field bean, rice, and maize [10].

The objective of this study was to investigate the effects of varying rates of $\mathrm{N}$ ( 62 to $248 \mathrm{~kg} \mathrm{ha}^{-1}$ ) with or without SoxB, and combined effects of SoxB and nitrogen-fixing bacteria $(\mathrm{NFxB})$ on onion yield, quality, and nutrient uptake on a newly reclaimed soil.

\section{Materials and Methods}

Field experiment was conducted at El-Saff region, Giza Governorate, South of Cairo, Egypt, located between $29^{\circ}$ $38^{\prime} 25.1^{\prime \prime} \mathrm{N}$ and $31^{\circ} 19^{\prime} 26.8^{\prime \prime} \mathrm{E}$. Average annual rainfall in this region is only about 2 to $5 \mathrm{~mm}$. During the winter growing season of 2007-2008, average temperature was 13 to $21^{\circ} \mathrm{C}$. Wind storms from the south (referred to as "Khamaseen"), usually in spring or summer, brings sand and dust, and sometimes raises the temperature in the desert to more than $38^{\circ} \mathrm{C}$. The physical and chemical properties of the surface soil $(0-30 \mathrm{~cm})$ determined according to Page et al. [11] and FAO [12] include the revealed contents of sand, clay, and silt as $87.6,6.8$, and $5.6 \%$, respectively. The other properties include organic matter $=0.35 \%, \mathrm{CaCO}_{3}=12.7 \%$, concentrations of available $\mathrm{N}, \mathrm{P}, \mathrm{K}$, and S were 15.3, 10.6, 65.7, and $7.4 \mathrm{mg} \mathrm{kg}^{-1}$, respectively, with $\mathrm{pH}=7.80$ and $\mathrm{EC}=2.3 \mathrm{dS} \mathrm{m} \mathrm{m}^{-1}$. Onion (Allium cepa L-cultivar: Giza 20) seedlings were planted $10 \mathrm{~cm}$ apart on the two sides of row spaced $0.5 \mathrm{~m}$, with plot area of $3 \mathrm{~m}^{2}(1.5 \times 2 \mathrm{~m})$.

The following treatments were evaluated in a randomized complete block design with three replicates: (i) control, that is, soil with no inoculation or $\mathrm{N}$ fertilizers (CK),

(ii), (iii), and (iv) received 62, 124, and $248 \mathrm{~kg} \mathrm{ha}^{-1} \mathrm{~N}$ application, respectively $(62 \mathrm{~N}, 124 \mathrm{~N}$, and $248 \mathrm{~N})$,

(v) to (vii) are treatments similar to (ii) to (iv) with inoculation of $\mathrm{S}$ oxidizing bacteria (SoxB): $(62 \mathrm{~N}+$ SoxB; $124 \mathrm{~N}+$ SoxB; $248 \mathrm{~N}+$ SoxB),

(viii) no $\mathrm{N}$ fertilizer, plus inoculation of SoxB and $\mathrm{N}$ fixing bacteria $(\mathrm{NFxB})$ : $(\mathrm{CK}+\mathrm{SoxB}+\mathrm{NFxB})$.

Super phosphate $(6.8 \% \mathrm{P})$ and potassium sulphate $(43 \%$ K) were broadcasted at quantities equivalent to 494 and $247 \mathrm{~kg} \mathrm{ha}^{-1}$, respectively, and incorporated with soil before planting. Nitrogen fertilizer was applied as ammonium nitrate $(33.5 \% \mathrm{~N})$ in three applications, that is, at sowing, plus two applications at monthly interval. All treatments received elemental sulfur (S) at $620 \mathrm{~kg} \mathrm{ha}^{-1}$ and $25 \mathrm{Mg} \mathrm{ha}^{-1}$ organic manure incorporated before planting. Irrigation was done once every 48 hrs by drip system with one drip tape per row and drippers with $4 \mathrm{Lh}^{-1}$ discharge rate spaced at $0.33 \mathrm{~m}$.

2.1. Microorganisms Used and Method of Inoculation. The various microorganisms used in this study include SoxB and $\mathrm{NFxB}$ with establishment of their growth parameters. The methodologies used are given below.

2.2. Thiobacillus Thiooxidans (Sulfur-Oxidizing Bacteria $($ SoxB)). Thiobacillus thiooxidans strain was isolated and identified at the Agricultural Microbiology Department, National Research Center [13], Cairo, Egypt. Bacterial cultures were grown in $250 \mathrm{~mL}$ Erlenmeyer flasks using Starkey's medium [14] at $30^{\circ} \mathrm{C}$ for 4 weeks on shaker at $220 \mathrm{rpm}$. The density of bacterial culture in the broth counted using optical density was $10^{8} \mathrm{CFU} \mathrm{mL} \mathrm{mL}^{-1}$ before being used to fortify with organic manure. Inoculation treatments were applied at the rate of $100 \mathrm{~mL} \mathrm{plot}^{-1}$ mixed with weighed amount of organic manure and then broadcast uniformly into the plot area.

2.3. Free Nitrogen-Fixing Bacteria (NFxB). Highly efficient strains of plant growth promoting rhizobacteria (PGPR) (Azotobacter chroococcum and Azospirillum lipoferum) were selected from culture collection of Agricultural Microbiology Department, National Research Center, Cairo, Egypt. Azospirillum was maintained at $30^{\circ} \mathrm{C}$ on malate-yeast extract medium, while Azotobacter was kept on Ashby's mannitol agar. The Azotobacter and Azospirillum were independently grown in nutrient broth for 48 hours at $30^{\circ} \mathrm{C}$ in a rotary shaking incubator. The density of Azotobacter and Azospirillum in the broth was $10^{7}$ and $10^{6}$ of $\mathrm{CFU} \mathrm{mL} \mathrm{m}^{-1}$, respectively. One hundred $\mathrm{mL}$ each of liquid broth cultures of Azotobacter and Azospirillum initially containing $7 \times 10^{8}$ and $5 \times 10^{7}$ viable cell $\mathrm{mL}^{-1}$, respectively, was mixed with preweighed quantity of organic manure per plot, which was then uniformly distributed over the plot surface area.

2.4. Response Parameters. Soil sample was taken from 0 to $15 \mathrm{~cm}$ depth from each plot on $7,15,30,60,90$, and 120 
days after planting for analysis of water-soluble sulphate and $\mathrm{pH}$. Plant samples were collected at the maturity stage (150 days) to measure leaf length, fresh and dry weights of leaves and bulbs, and total yield. Concentrations of N, P, K, Zn, Fe, and $\mathrm{Mn}$ in plants were determined according to Kalra and Maynard [15].

The data obtained as average of the two successive seasons were subjected to two-way analysis of variance (ANOVA) to test the significance of treatment effects. Test of significance for differences in means was done using leastsquare difference (LSD) described by Snedecor and Cochran [16].

\section{Results and Discussion}

3.1. Effects of $S$ Oxidation in Onion Rhizosphere on Some Soil Properties. Oxidation of $\mathrm{S}$ in onion rhizosphere was monitored based on $\mathrm{SO}_{4}{ }^{2-}$ concentration at various durations during the plant growing period (Figure 1). The $\mathrm{SO}_{4}{ }^{2-}$ concentration increased with increasing rate of $\mathrm{N}$ (62 to $248 \mathrm{~kg} \mathrm{ha}^{-1}$ ). Furthermore, inoculation with SoxB increased the $\mathrm{SO}_{4}$ concentration across all $\mathrm{N}$ rates. Combined inoculation of SoxB and NFxB (with no N applied) did not appear to enhance $S$ oxidation as compared to inoculation of only SoxB. Most agricultural soils contain an abundance of native SoxB population; hence, SoxB inoculation may not be necessary. However, some soils do respond to SoxB inoculation as was the case in this study. Our results agree with that of Kapoor and Mishra [17] who reported rapid oxidization of $\mathrm{S}$ in a field soil with $\mathrm{pH} 8.0$, and the rate of oxidation was further enhanced by SoxB inoculation.

The $\mathrm{SO}_{4}{ }^{2-}$ concentration in the soil increased from 7 to 30 days after planting (DAP), by 38,35 to 56,52 to 68 , and $56 \%$, respectively, in control, 62 to $248 \mathrm{~kg} \mathrm{ha}^{-1} \mathrm{~N}$ rate, different $\mathrm{N}$ rates plus SoxB inoculation, and SoxB and NFxB inoculation treatments. Subsequently, the $\mathrm{SO}_{4}{ }^{2-}$ concentration decreased until 120 DAP. The corresponding percent reductions for the above treatments between 30 and 120 DAP were 45,40 to 43,29 to 30 , and $31 \%$. These results suggest that in the soil with SoxB inoculation, the increase in $\mathrm{SO}_{4}{ }^{2-}$ concentration during 7 to $30 \mathrm{DAP}$ was greater and decrease during 30 to $120 \mathrm{DAP}$ was lower as compared to that in the soil without SoxB inoculation. Leaching of $\mathrm{SO}_{4}{ }^{2-}$ below the depth of soil sampling may account, in part, for this reduction in $\mathrm{SO}_{4}{ }^{2-}$ concentration. Net mineralization of $\mathrm{S}$ was significantly greater in SoxB-inoculated soils compared to that in noninoculated soils.

3.2. Changes in Soil pH in Onion Rhizosphere. Across most treatments, the soil $\mathrm{pH}$ somewhat decreased or remained unchanged from 7 to $30 \mathrm{DAP}$, followed by gradual increase during 60 and 90 DAP with highest $\mathrm{pH}$ values on $120 \mathrm{DAP}$ (Figure 2). The initial decrease in $\mathrm{pH}$ values might be ascribed to $\mathrm{H}^{+}$ion released during $\mathrm{S}$ oxidation. When elemental $S$ is applied to soil, a biological reaction takes place carried out by SoxB, producing sulfuric acid that reduces soil $\mathrm{pH}$ [18]. The analysis of field soil samples taken after harvest revealed that soil inoculation of SoxB reduced soil $\mathrm{pH}$ from

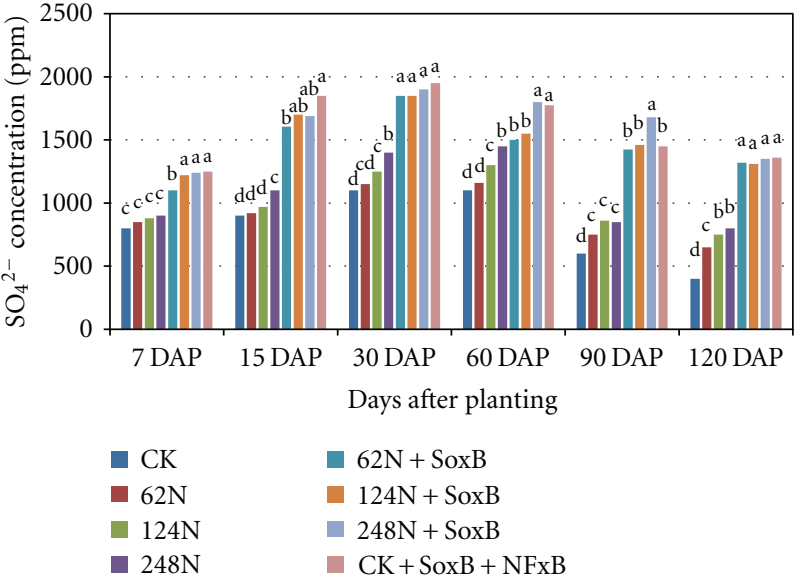

FIGURE 1: Changes in $\mathrm{SO}_{4}{ }^{2-}$ concentration in onion rhizosphere soil over 120 days after planting (DAP). Means followed by the same letters, by each sampling date, are not significantly different as per Duncan's multiple range test at $P \leq 0.05$.

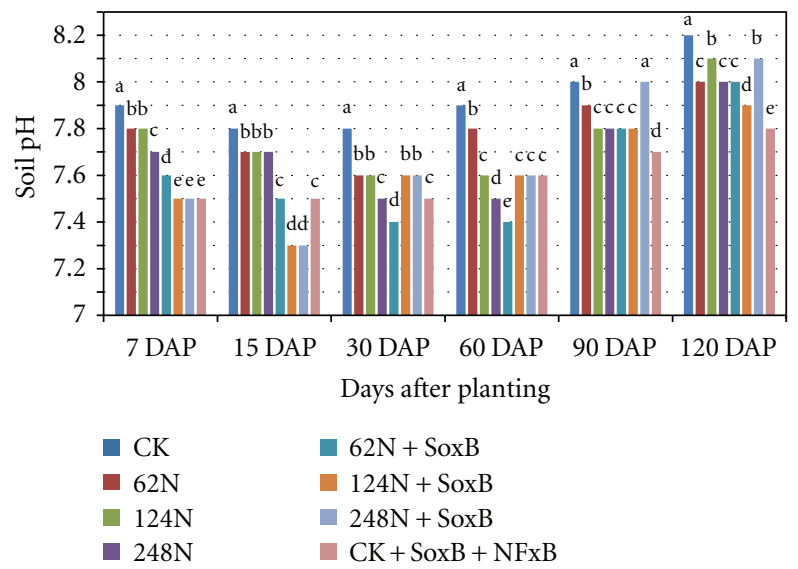

FIgURE 2: Change in soil $\mathrm{pH}$ in onion rhizosphere soil over 120 days after planting (DAP). Means followed by same letters, by each sampling date, are not significantly different as per Duncan's Multiple Range test at $P \leq 0.05$.

7.8 to 7.5. Anandham et al. [19] reported that inoculation of SoxB also increased available soil- $S$ from 7.4 to $8.43 \mathrm{~kg} \mathrm{ha}^{-1}$, and EC from 0.20 to $0.25 \mathrm{dS} \mathrm{m}^{-1}$. Anandham et al. [19] also reported that the soil $\mathrm{pH}$ decreased from 7.2 to 7.0; however, no negative effects were evident on plant growth. A study on peanut production revealed that application of elemental $\mathrm{S}\left(0.6 \mathrm{Mg} \mathrm{ha}^{-1}\right)$ and inoculation of Thiobacillus significantly reduced the soil $\mathrm{pH}$ from 8.2 to 7.1 at the end of the growing period [20]. Decrease in soil $\mathrm{pH}$ is desirable in calcareous and saline soils for improved plant growth and adequate micronutrient availability.

3.3. Plant Growth and Yield. Onion plant height increased by $32 \%$ with $62 \mathrm{~kg} \mathrm{ha}^{-1} \mathrm{~N}$ rate as compared to that grown with no $\mathrm{N}$ application (Table 1). Further increment in $\mathrm{N}$ rate had no significant influence on the plant height. Soil inoculation with SoxB at different $\mathrm{N}$ rates failed to show any beneficial 
TABLE 1: Effects of different rates of nitrogen $\left(\mathrm{kg} \mathrm{ha}^{-1}\right)$ without or with inoculation of sulfur-oxidizing bacteria (SoxB) and soil inoculated with SoxB and N-fixing Bacteria (NFxB) on onion plant growth parameters and bulb yield.

\begin{tabular}{|c|c|c|c|c|c|c|}
\hline Treatments & Plant height $(\mathrm{cm})$ & Onion yield & Fresh bulb & $\begin{array}{l}\text { Dry bulb } \\
\left(\mathrm{Mg} \mathrm{ha}^{-1}\right)\end{array}$ & Fresh leaves & Dry leaves \\
\hline CK & 34 & 13.1 & 11.1 & 1.56 & 1.61 & 0.37 \\
\hline $62 \mathrm{~N}$ & 45 & 16.8 & 14.1 & 2.25 & 2.35 & 0.59 \\
\hline $124 \mathrm{~N}$ & 49 & 19.0 & 15.3 & 2.35 & 3.24 & 0.67 \\
\hline $248 \mathrm{~N}$ & 52 & 23.0 & 18.8 & 2.87 & 3.95 & 0.91 \\
\hline $62 \mathrm{~N}+\mathrm{SoxB}$ & 44 & 28.4 & 22.7 & 3.36 & 4.77 & 0.96 \\
\hline $124 N+$ SoxB & 46 & 30.4 & 25.2 & 3.78 & 5.98 & 1.01 \\
\hline $248 \mathrm{~N}+$ SoxB & 48 & 33.8 & 27.9 & 4.32 & 6.40 & 1.09 \\
\hline $\mathrm{CK}+\mathrm{SoxB}+\mathrm{NFxB}$ & 55 & 42.0 & 34.8 & 5.58 & 8.32 & 1.58 \\
\hline${ }^{1} \mathrm{LSD}$ at 0.05 & 8 & 4.0 & 3.0 & 0.64 & 1.06 & 0.02 \\
\hline
\end{tabular}

${ }^{1}$ LSD: least significant difference.

TABLE 2: Effect of nitrogen and soil inoculation with sulfur-oxidizing (SoxB) and nitrogen-fixing bacteria (NFxB) on nutrient uptake by onion plants.

\begin{tabular}{|c|c|c|c|c|c|c|}
\hline \multirow{2}{*}{ Treatments } & \multicolumn{3}{|c|}{ Macronutrients uptake $\left(\mathrm{kg} \mathrm{ha}^{-1}\right)$} & \multicolumn{3}{|c|}{ Micronutrients (ppm) } \\
\hline & $\mathrm{N}$ & $\mathrm{P}$ & $\mathrm{K}$ & $\mathrm{Zn}$ & $\mathrm{Fe}$ & $\mathrm{Mn}$ \\
\hline CK & 24.9 & 1.7 & 24.2 & 7.5 & 2.4 & 15.7 \\
\hline $62 \mathrm{~N}$ & 40.0 & 3.5 & 32.6 & 16.7 & 5.7 & 27.7 \\
\hline $124 \mathrm{~N}$ & 51.4 & 4.7 & 39.0 & 32.9 & 14.2 & 35.8 \\
\hline $248 \mathrm{~N}$ & 61.0 & 5.9 & 49.9 & 75.0 & 31.7 & 37.0 \\
\hline $62 \mathrm{~N}+$ SoxB & 77.1 & 6.4 & 58.8 & 78.4 & 42.9 & 40.0 \\
\hline $124 \mathrm{~N}+\mathrm{SoxB}$ & 90.4 & 7.4 & 70.1 & 81.0 & 44.9 & 40.3 \\
\hline $248 \mathrm{~N}+$ SoxB & 108.7 & 10.4 & 85.7 & 88.8 & 47.1 & 42.7 \\
\hline $\mathrm{CK}+\mathrm{SoxB}+\mathrm{NFxB}$ & 181.5 & 14.6 & 114.9 & 99.8 & 56.0 & 57.1 \\
\hline${ }^{1} \mathrm{LSD}$ at 0.05 & 21.2 & 1.5 & 19.3 & 6.9 & 8.3 & 10.8 \\
\hline
\end{tabular}

${ }^{1}$ LSD: least significant difference.

effects on plant height. Height of the plants grown in the soil inoculated with SoxB and NFxB (no N), and the soil received 62 to $248 \mathrm{~kg} \mathrm{ha}^{-1} \mathrm{~N}$ rates were greater by $62 \%$ and 32 to $53 \%$, respectively, as compared to that of the plants grown in the soil with no $\mathrm{N}$ and no inoculation. Highest onion yield was also obtained in the soil inoculated with SoxB and NFxB (Table 1), followed by the soil with $248 \mathrm{~kg} \mathrm{ha}^{-1} \mathrm{~N}$ and SoxB inoculation. Inoculation with SoxB significantly increased the onion yield by 47 to $69 \%$ across different $\mathrm{N}$ rates, as compared to that of the plants that received respective $\mathrm{N}$ rates but not SoxB inoculation. The onion yield was the lowest in soil with no inoculation and no $\mathrm{N}$ application. Nitrogen and $\mathrm{S}$ appear to exert strong effects on various growth parameters of onion plants and flavor biosynthetic pathway [21]. Songzhong et al. [1] investigated the effects of different $\mathrm{N}$ supply levels $\left(1.5,3.0,6.0,12.0\right.$, and $24.0 \mathrm{mmol} \mathrm{L}^{-1}$ of $\mathrm{N}$ ) in Chinese spring onion (Allium fistulosum L. var giganteum Makino) in soilless growing media. High $\mathrm{N}$ rate $\left(24 \mathrm{mmol} \mathrm{L}^{-1}\right)$ significantly inhibited plant growth, retarded $\mathrm{S}$ assimilation, and decreased pungency. However, $\mathrm{N}$ rates in the range of 360 to $600 \mathrm{~kg} \mathrm{~N} \mathrm{ha}^{-1}$ are common in Zhangqin County, China, despite the recommended rate of only $240 \mathrm{~kg} \mathrm{~N} \mathrm{ha}^{-1}$ for a target yield of $60 \mathrm{Mg} \mathrm{ha}^{-1}$ [22].
Sulfur-based fertilizers decrease the $\mathrm{pH}$ of soil and, thus, increase the uptake of other plant nutrients, which contributes to increased yields. The results of our study are in agreement with that of Sullivan et al. [23], Sutaliya et al. [24], and El-Desuki et al. [25]. Smatanová et al. [26] reported that the application of $\mathrm{S}$ as $\left(\mathrm{NH}_{4}\right)_{2} \mathrm{SO}_{4}$ had positive effects on yields and quality of the vegetables. Anandham et al. [19] reported that inoculation of both Thiobacillus and Rhizobium increased the shoot height, root length, and plant biomass on 40 and 80 days after seeding in pot and field experiments as compared to the plants inoculated with single strain. Banerjee and Yesmin [27] discovered that the use of S-oxidizing rhizobacteria in combination with elemental $S$ increased canola yield in S-deficient soils. Thus, they concluded that S-oxidizing rhizobacteria was effective to enhance canola production.

Whipps [28] stated that the importance of plant growthpromoting rhizobacteria (PGPR) was well established and to some extent, the beneficial effects of PGPR may be linked to biocontrol. PGPR increases plant growth indirectly either by the suppression of well-known diseases caused by major pathogens or by reducing the deleterious effects of minor pathogen, that is, microorganisms which reduce plant 
growth but without obvious symptoms. Yesmin and Banerjee [29] isolated S oxidizers among the rhizobacterial strains and that these bacteria were critical to meet plant $S$ demand while utilizing elemental S. These S oxidizers had stimulating effect on canola plant emergence. Results indicated that bacterial inoculation enhanced canola biomass and yield. Okon and Labandera-Gonzalez [30] reported wheat yield increase of up to $30 \%$ in $60-70 \%$ of the trials with S oxidizers. Yield increases have been attributed to mechanisms such as $\mathrm{N}$ fixation, phytohormone, and nitrate reduction.

The response to rhizobacteria inoculation depends on different factors, including inoculation, chances for survival and motility, adsorption by soil particles, competition with indigenous populations of rhizobacteria, and soil fertility [31, 32]. Some soil microorganisms, like Azospirillum sp. [33], Enterobacter sp., Azotobacter sp., and Pseudomonas sp. [34], have shown to encourage plant growth [35] by promoting the outbreak of secondary roots, acting as protectors against pathogenic microorganisms by release of plant hormones and siderophores [36].

3.4. Nutrients Uptake in Onion Bulbs. Uptake of most nutrients was high in the plants grown in soil inoculated with SoxB and NFxB, followed by that in plants received $\mathrm{N}$ rates plus SoxB, only $\mathrm{N}$, and soil without $\mathrm{N}$ or inoculation (Table 2). This trend also supports the trend in onion yields and, thus, increased nutrient uptake by a given soil treatment contributed to increased bulb yield (Tables 1 and 2). The reduction in soil $\mathrm{pH}$ with inoculation of SoxB and NFxB may have contributed to increased availability of micronutrients which in turn lead to increased micronutrient uptake (Table 2). Concentration of $\mathrm{N}$ in onion bulbs was greater in plants grown in soil inoculated with SoxB and NFxB. These results agree with those reported by Rizk [37] and El-Desuki et al. [25] who concluded that adequate $\mathrm{N}$ and $\mathrm{S}$ availability was critical for increasing the yield.

\section{Conclusion}

The results of this study demonstrate the beneficial effects of application of $\mathrm{N}$ and elemental $\mathrm{S}$ along with inoculation of SoxB and NFxB on onion yields. Balanced fertilization is essential to increase yields and net returns while minimizing nutrient loss to the environment. However, more field studies under different agroclimatic conditions are required to confirm the above findings.

\section{References}

[1] L. Songzhong, H. He, G. Feng, and Q. Chen, "Effect of nitrogen and sulfur interaction on growth and pungency of different pseudostem types of Chinese spring onion (Allium fistulosum L.)," Scientia Horticulturae, vol. 121, no. 1, pp. 12$18,2009$.

[2] R. W. Howarth, J. W. B. Stewart, and M. V. Ivanov, "Sulphur cycling on the continents," in Scientific Committee on Problems of the Environment, vol. 48, p. 350, John Wiley \& Sons, New York, NY, USA, 1992.

[3] A. Abd-Elfattah, M. S. M. Saber, and M. H. Hilal, "The use of Thiobacillus in regulating the metabolism in clay loam soil supplemented with elemental sulphur," Egyptian Journal of Soil Science, vol. 31, pp. 333-341, 1991.

[4] S. Haneklaus, E. Bloem, and E. Schnug, "The global sulphur cycle and its link to plant environment," in Sulphur in Plants, pp. 1-28, Kluwer Academic Publishers, Dordrecht, The Netherlands, 2003.

[5] H. W. Scherer, "Sulphur in crop production-invited paper," European Journal of Agronomy, vol. 14, no. 2, pp. 81-111, 2001.

[6] M. A. Kertesz and P. Mirleau, "The role of soil microbes in plant sulphur nutrition," Journal of Experimental Botany, vol. 55, no. 404, pp. 1939-1945, 2004.

[7] F. J. Zhao, M. J. Hawkesford, and S. P. McGrath, "Sulphur assimilation and effects on yield and quality of wheat," Journal of Cereal Science, vol. 30, no. 1, pp. 1-17, 1999.

[8] M. Wainright, "Sulphur oxidation in soilsAdvanced Agronomy," Advanced Agronomy, vol. 37, pp. 350-392, 1984.

[9] I. Suzuki, "Oxidation of inorganic sulfur compounds: Chemical and enzymatic reactions," Canadian Journal of Microbiology, vol. 45, no. 2, pp. 97-105, 1999.

[10] K. Hitsuda, M. Yamada, and D. Klepker, "Sulfur requirement of eight crops at early stages of growth," Agronomy Journal, vol. 97, no. 1, pp. 155-159, 2005.

[11] A. L. Page, R. H. Miller, and D. R. Keeney, Methods of Soil Analysis. Part2. Chemical and Micro-Biological Properties, American Society for Agronomy, Madison, Wis, USA, 2nd edition, 1982.

[12] FAO, Guidelines to Soil Description, FAO Publishing, 1970.

[13] A. M. Nemat and K. M. A. Khalil, "Biofertilization of squash plants grown in sulphur rectified sandy soil with Streptomyces venezuelae mutant and/or Thiobacillus thiooxidans," Bulletin of the National Research Center, vol. 28, pp. 658-694, 2003.

[14] R. L. Starkey, "Cultivation of organisms concerned in the oxidation of thiosulfate," Journal of Bacteriology, vol. 28, pp. 365-386, 1934.

[15] Y. P. Kalra and D. G. Maynard, Methods Manual for Forest Soil, Forestry Canada Northern Forestry Centre, 1995.

[16] G. W. Snedecor and W. G. Cochran, Statistical Methods, Iowa State University, Ames, Iowa, USA, 7th edition, 1982.

[17] K. K. Kapoor and M. M. Mishra, "Microbial transformation of sulphur and plant nutrition," in Soil Microorganisms and Crop Growth, pp. 1-30, 1989.

[18] J. A. Lucas García, A. Probanza, B. Ramos, J. Barriuso, and F. J. Gutierrez Mañero, "Effects of inoculation with plant growth promoting rhizobacteria (PGPRs) and Sinorhizobium fredii on biological nitrogen fixation, nodulation and growth of Glycine max cv. Osumi," Plant and Soil, vol. 267, no. 1-2, pp. 145-153, 2005.

[19] R. Anandham, R. Sridar, P. Nalayini, S. Poonguzhali, M. Madhaiyan, and S. Tongmin, "Potential for plant growth promotion in groundnut (Arachis hypogaea L.) cv. ALR-2 by co-inoculation of sulfur-oxidizing bacteria and Rhizobium," Microbiological Research, vol. 162, no. 2, pp. 139-153, 2007.

[20] N. P. Stamford, A. J. N. Silva, A. D. S. Freitas, and A. J. Filho, "Effect of sulphur inoculated with Thiobacillus on soil salinity and growth of tropical tree legumes," Bioresource Technology, vol. 81, no. 1, pp. 53-59, 2002.

[21] T. W. Coolong and W. M. Randle, "Sulfur and nitrogen availability interact to affect the flavor biosynthetic pathway in onion," Journal of the American Society for Horticultural Science, vol. 128, no. 5, pp. 776-783, 2003.

[22] L. H. Jiang, Z. H. Liu, Q. Chen, H. T. Lin, and W. J. Zhang, "Study on the effect of nitrogen on green Chinese onion yield and N supplying target value," Plant Nutrition and Fertilizer Science, vol. 13, pp. 890-896, 2007. 
[23] D. M. Sullivan, B. D. Brown, C. C. Shock et al., "Nutrient management for onion in the pacific northwest. A pacific northwest extension publication, Oregon State University, Washington State University, and University of Idaho," PNW 546, 2001.

[24] R. Sutaliya, A. K. Gupta, and R. N. Singh, "Yield attributes of barley as influenced by phosphorus, sulphur and their correlation and regression with yield," Crop Research, vol. 25, pp. 585-586, 2003.

[25] M. EL-Desuki, A. R. Mahmoud, and M. M. Hafiz, "Response of onion plants to minerals and bio-fertilizers application," Research Journal of Agriculture and Biological Sciences, vol. 2, pp. 292-298, 2006.

[26] M. Smatanová, R. Richter, and J. Hlušek, "Spinach and pepper response to nitrogen and sulphur fertilization," Plant, Soil and Environment, vol. 50, no. 7, pp. 303-308, 2004.

[27] M. R. Banerjee and L. Yesmin, "Sulfur oxidizing rhizobacteria: an innovative environment friendly soil biotechnological tool for better canola production," Proceedings of the AgroEnvironment, vol. October, pp. 1-7, 2002.

[28] J. M. Whipps, "Microbial interactions and biocontrol in the rhizosphere," Journal of Experimental Botany, vol. 52, pp. 487$511,2001$.

[29] L. Yesmin and M. R. Banerjee, "Bacterial viability and biological seed treatment of canola," Proceedings of Soils \& Crops, pp. 314-319, 2001.

[30] Y. Okon and C. A. Labandera-Gonzalez, "Agronomic applications of Azospirillum: an evaluation of 20 years worldwide field inoculation," Soil Biology and Biochemistry, vol. 26, no. 12, pp. 1591-1601, 1994.

[31] Y. Bashan, M. E. Puente, M. N. Rodriguez-Mendoza et al., "Survival of Azospirillum brasilense in the bulk soil and rhizosphere of 23 soil types," Applied and Environmental Microbiology, vol. 61, no. 5, pp. 1938-1945, 1995.

[32] H. Levanony, Y. Bashan, and Z. E. Kahana, "Enzyme-linked immunosorbent assay for specific identification and enumeration of Azospirillum brasilense Cd. in cereal roots," Applied and Environmental Microbiology, vol. 53, pp. 358-364, 1987.

[33] W. Zimmer and H. Bothe, "The phytohormonal interactions between Azospirillum and wheat," Plant and Soil, vol. 110, no. 2, pp. 239-247, 1988.

[34] A. Gamliel and J. Katan, "Chemotaxis of fluoresent Pseudomonas towards seed exudates and germinating seeds in solarized soil," Ecology and Epidemiology, vol. 82, pp. 328-332, 1992.

[35] R. Arteca, Plant Growth Substances, Chapman and Hall, New York, NY, USA, 1996.

[36] B. Amstron, A. Gustafsson, and B. Gerharsson, "Characteristics of a plant deleterious rhizosphere pseudomonad and its inhibitory metabolite (s)," Journal of Applied Bacteriology, vol. 74, pp. 20-28, 1993.

[37] A. F. Rizk, "Productivity of onion plant (Allium cepa L.) as affected by method of planting and NPK application," Egyptian Journal of Horticulture, vol. 24, pp. 219-238, 1997. 


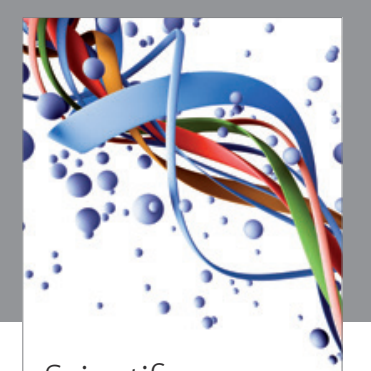

Scientifica
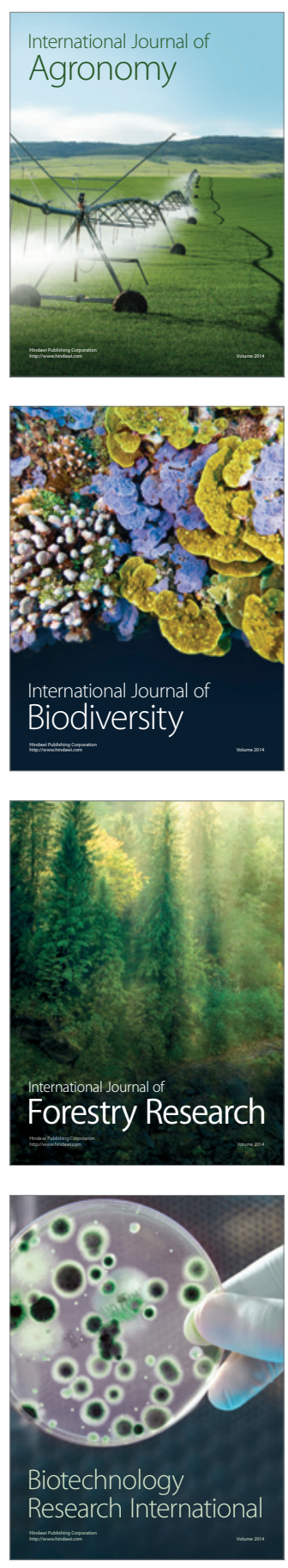
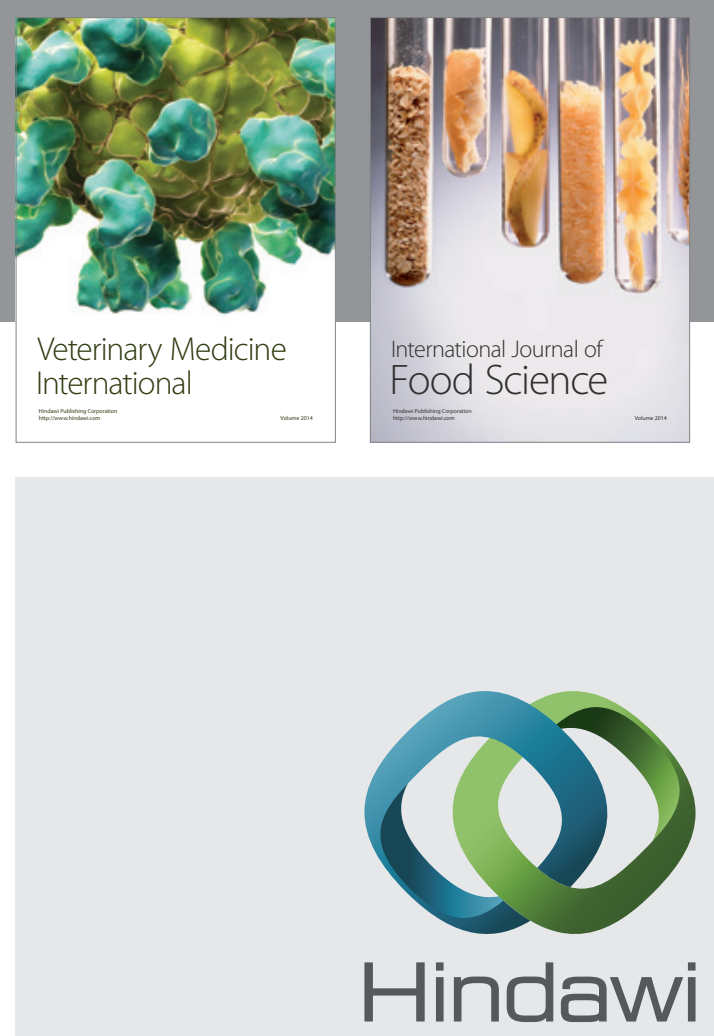

Submit your manuscripts at

http://www.hindawi.com
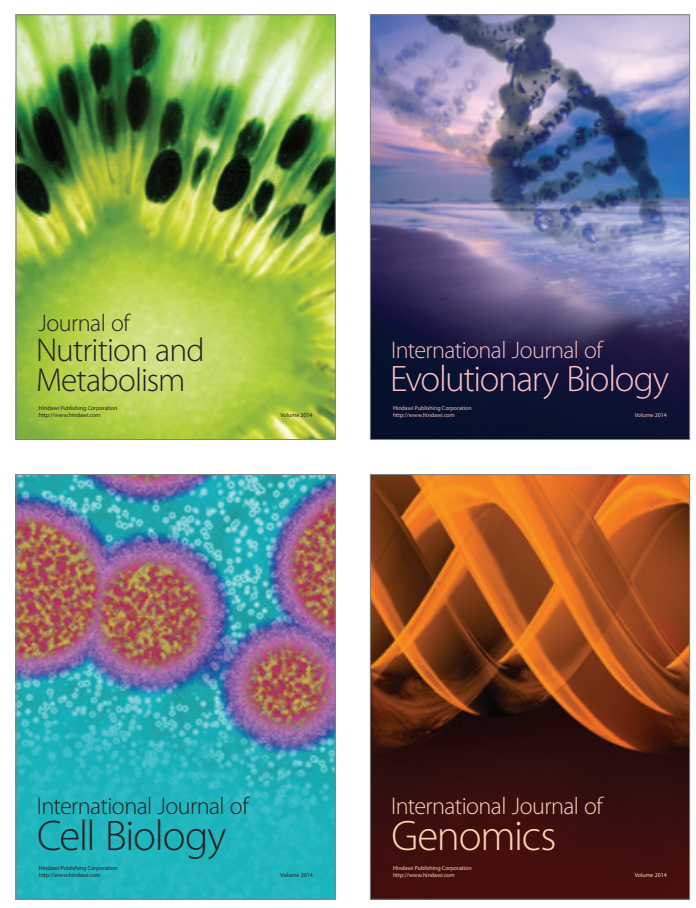
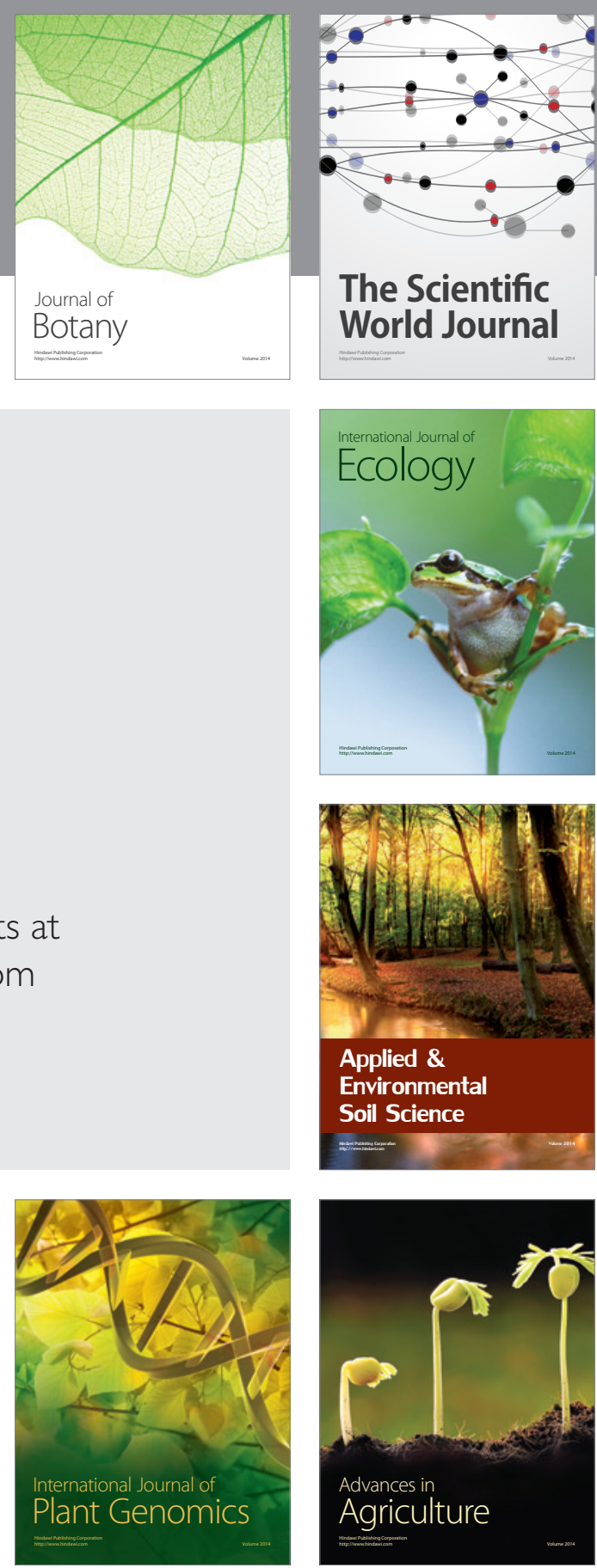

The Scientific World Journal
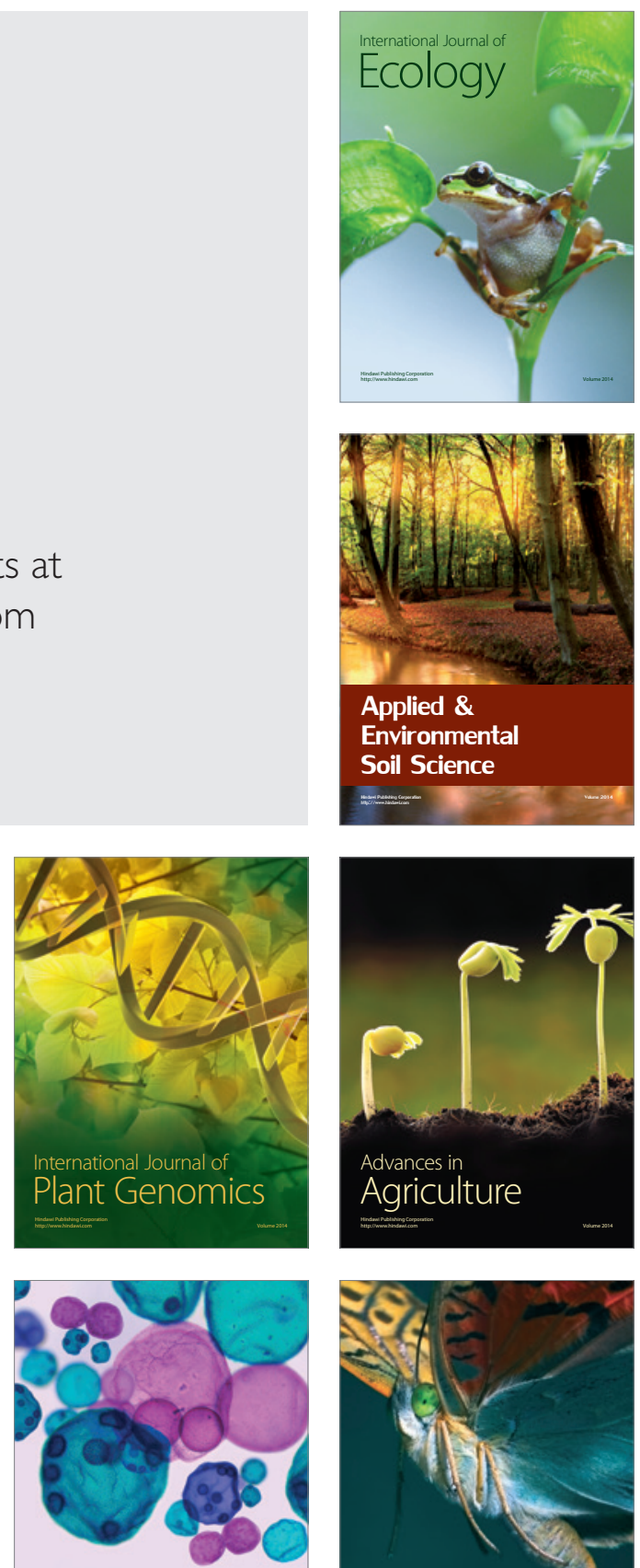

International Journal of Microbiology

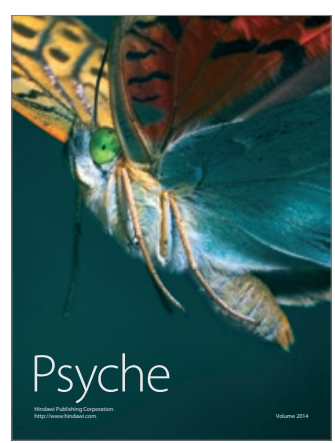

